\title{
Comparison of the early effects of out-of-hospital resuscitation in selected urban and rural areas in Poland. A preliminary report from the Polish Cardiac Arrest Registry by the Polish Resuscitation Council
}

\author{
Grzegorz M. Cebula ${ }^{1}$, Sonia Osadnik ${ }^{1}$, Michał Wysocki ${ }^{1}$, Marta Dyrda ${ }^{1}$, Kaja Chmura ${ }^{2}$, \\ Michał Nowakowski², Janusz Andres ${ }^{1}$ \\ ${ }^{1}$ Faculty of Medicine, Department of Anaesthesiology and Intensive Care, Jagiellonian University Medical College, Krakow, Poland \\ ${ }^{2}$ Faculty of Medicine, Department of Medical Education, Jagiellonian University Medical College, Krakow, Poland
}

\begin{abstract}
Background: The chain of survival is a set of most important factors affecting survival after an out-of-hospital cardiac arrest (OHCA). Recognising the difficulties in applying the chain is the key to improving outcomes. Early return of spontaneous circulation (ROSC) after a cardiac arrest is a fundamental factor for patient survival.

Aim: To assess the degree to which the location of OHCA affects ROSC during resuscitation efforts.

Methods: Emergency medical service (EMS) teams filled cardiac arrest forms based on standard (Utstein) guidelines. The registry covered data from January 2013 to May 2014 collected over the area of $23,706 \mathrm{~km}^{2}$ with the population density of 90 persons $/ \mathrm{km}^{2}$. This constitutes $7.6 \%$ of the area of Poland. The average population density in Poland is 123 persons $/ \mathrm{km}^{2}$.

Results: Over the time period covered by the study, 5185 cases of OHCA were reported. Resuscitation was attempted in 2415 (46.6\%) cases. ROSC was achieved in 736 (30.48\%) cases, including 374 (32.13\%) cases in urban areas and 362 (28.94\%) cases in rural areas. This difference was not statistically significant. Compared to urban areas, event witnesses in rural areas were more likely to perform bystander resuscitation and receive instructions from the EMS dispatchers. In the whole study group, cardiac disorders were the most common underlying cause of cardiac arrest (70.35\%). The median time of ambulance arrival to the scene was significantly shorter in urban areas compared to rural areas (median time 6 min and 12 min, respectively).

Conclusions: No significant relation was found between the location of OHCA and ROSC despite the fact that the time to ambulance arrival was significantly shorter in urban areas. In rural areas, resuscitation was more frequently initiated by the event witnesses. Both in urban and rural areas, OHCA was most commonly due to cardiac causes, and the initial recorded cardiac rhythm was a non-shockable one.
\end{abstract}

Key words: cardio-pulmonary resuscitation, out-of-hospital cardiac arrest, rural and urban areas, chain of survival, return of spontaneous circulation

Kardiol Pol 2016; 74, 4: 356-361

\section{INTRODUCTION}

Out-of-hospital cardiac arrest (OHCA) remains a major clinical problem worldwide. Studies show that 300,000 to 700,000 cases of OHCA occur each year in Europe [1], and the annual number of such events in the United States is more than 350,000 [2]. The 2015 European Resuscitation Council guidelines [1] highlight the importance of increasing public knowledge regarding resuscitation. The most important factors

\section{Address for correspondence:}

Grzegorz M. Cebula, MD, PhD, Faculty of Medicine, Department of Anaesthesiology and Intensive Care, Jagiellonian University Medical College, ul. M. Kopernika 17, 31-501 Kraków, Poland, e-mail: grzegorz.cebula@uj.edu.pl Received: 02.11.2015 Accepted: 21.12.2015 Available as AoP: 07.01.2015

Kardiologia Polska Copyright (c) Polskie Towarzystwo Kardiologiczne 2016 
affecting survival following a cardiac arrest are illustrated by the concept of the chain of survival [3] which includes four components: early diagnosis and call for help, immediate initiation of cardiopulmonary resuscitation (CPR) by other people witnessing the event, early defibrillation if indicated, and postresuscitation therapy. Every component of the chain of survival has a significant effect on increasing the chance of patient survival in good neurological condition. Ideally, all these measures should be instituted as early as possible and in accordance with the current guidelines. However, multiple factors may delay these procedures or even make them impossible. As a result, survival until hospital discharge following $\mathrm{OHCA}$ is low, in the range of few to several per cent $[4,5]$. Available evidence shows that successful introduction of the concept of the chain of survival, and particularly early defibrillation, may increase survival even above $50 \%$ in OHCA patients with a shockable rhythm $[6,7]$.

The aim of the study was to evaluate the effect of the location of OHCA on the return of spontaneous circulation (ROSC) following CPR initiated in selected urban and rural areas in Poland. ROSC is the major prerequisite of survival after a cardiac arrest.

Differences in the rate of ROSC in cardiac arrest patients between areas with a low population density and urban areas have been noted in the literature only in single Australian and Swedish studies $[8,9]$ and this issue has not been evaluated in Poland.

\section{METHODS}

We evaluated $\mathrm{OHCA}$ cases and resuscitation efforts until death or ROSC. Data were collected between January 1, 2013 and May 31, 2014 by Falck emergency medical services (EMS) teams participating in the Polish Cardiac Arrest Registry by the Polish Resuscitation Council. The study area covered $23,706 \mathrm{~km}^{2}$ in various parts of the country, with the mean population density of 90 persons $/ \mathrm{km}^{2}$. This corresponded to $7.6 \%$ of the area of Poland, and the mean population density in the whole country is 123 persons $/ \mathrm{km}^{2}$ [10].

All OHCA cases were divided into those occurring in the urban areas (localities with town privileges) and the rural areas (all other localities). Cities and towns included in the study had less than 100,000 inhabitants. Data were collected using forms compatible with an international standard (Utstein) [11], filled in by EMS teams immediately after the resuscitation efforts.

Overall, the study included 5185 cases of OHCA. We analysed 2415 cases in which resuscitation efforts were initiated by an EMS team. When comparing rural and urban areas, we took into account additional factors that might have affected ROSC in patients subjected to CPR, including witnessed cardiac arrest, initiation of CPR by the event witnesses, EMS dispatcher guidance to witnesses undertaking CPR, timing of ambulance arrival to the scene, causes of a cardiac arrest, and the initial recorded cardiac rhythm. The time of ambulance arrival to the scene was measured as the period from the first notification of an EMS dispatcher to ambulance arrival to the address indicated. The endpoint was ROSC or declaring the patient dead by the EMS team.

\section{Statistical analysis}

Statistical analysis was performed using the Statistica 10.0 PL software. The Pearson $\chi^{2}$ test for independence was used to verify whether a given relation was true and significant. The Mann-Whitney $U$ test was used to compare study variables between rural and urban OHCA groups.

\section{RESULTS}

Over the study period, 5185 OHCA events were reported. Resuscitation was attempted in 2415 (46.6\%) cases. ROSC was achieved in 736 cases, or $30.48 \%$ of patients in whom CPR was attempted. This included 374 cases of ROSC $(32.13 \%$ of patients) in urban areas and 362 cases (28.94\% of patients) in rural areas.

The rate of CPR attempts was similar in both groups, at $45.59 \%$ in urban areas and $47.53 \%$ in rural areas $(p=0.16)$.

Demographic data and detailed information regarding the course of OHCA in the study population are shown in Table 1.

Men predominated in both study groups, comprising about $70 \%$ of the overall study population. Differences in regard to gender and age distribution in both groups were not significant.

Most cases of OHCA were witnessed. Preceding symptoms were present in about half of study subjects. The differences reported above were not significant.

An association between initiation of CPR by event witnesses and location of OHCA was shown ( $p<0.001)$. In rural areas, CPR was initiated by event witnesses more frequently compared to urban areas, and witnesses were more frequently instructed by EMS dispatchers how to perform CPR $(p<0.001)$.

The mean time until ambulance arrival was significantly longer in rural areas, mean $13 \mathrm{~min} 10 \mathrm{~s}$ compared to $7 \mathrm{~min}$ $30 \mathrm{~s}$ in urban areas. The median time until ambulance arrival was $12 \mathrm{~min}$ and $6 \mathrm{~min}$, respectively.

Cardiac problems were most commonly diagnosed as a cause of OHCA by EMS teams both in rural areas (71.9\%) and in urban areas (68.8\%).

In all study subjects regardless of location of OHCA, non-shockable rhythms predominated in the initial recorded electrocardiogram (ECG). The rate of shockable rhythms was similar in urban and rural areas. Data on causes of OHCA and the initial recorded cardiac rhythm in urban and rural areas are shown in Table 2.

In a selected group of patients with witnessed OHCA due to cardiac causes and a shockable rhythm, ROSC was achieved in $43 \%$ of cases (78 patients) in rural areas and in $52 \%$ of cases (104 patients) in urban areas. This difference was not significant but a trend towards more frequent ROSC in urban areas was noted (Fig. 1). 
Table 1. Demographic data and detailed information regarding the course of out-of-hospital cardiac arrest (OHCA) in the study population

\begin{tabular}{|c|c|c|c|}
\hline & Urban areas & Rural areas & $\mathbf{P}$ \\
\hline Gender: & & & 0.08 \\
\hline Men & $789(67.8 \%)$ & $888(71.0 \%)$ & \\
\hline Women & $375(32.2 \%)$ & $363(29.0 \%)$ & \\
\hline Age (median) & 65 & 66 & 0.06 \\
\hline \multirow[t]{2}{*}{ Number of OHCA cases } & \multicolumn{2}{|c|}{5185} & \\
\hline & $2553(49.2 \%)$ & $2632(50.8 \%)$ & \\
\hline \multirow[t]{2}{*}{ CPR initiated by EMS } & \multicolumn{2}{|c|}{2415} & \\
\hline & $1164(45.59 \%)$ & $1251(47.53 \%)$ & 0.16 \\
\hline Time to ambulance arrival (median) [min] & 6 & 12 & 0.0000 \\
\hline \multicolumn{4}{|l|}{ Witnessed event: } \\
\hline Yes & $985(87.17 \%)$ & $1076(89.07 \%)$ & \multirow{2}{*}{0.15} \\
\hline No & $145(12.83 \%)$ & $132(10.93 \%)$ & \\
\hline \multicolumn{4}{|l|}{ Symptoms preceding OHCA: } \\
\hline Yes & $510(50.2 \%)$ & $541(48.7 \%)$ & \multirow{2}{*}{0.48} \\
\hline No & $506(49.8 \%)$ & $570(51.3 \%)$ & \\
\hline \multicolumn{4}{|c|}{ CPR initiated by the event witnesses before EMS arrival: } \\
\hline Yes & $464(39.86 \%)$ & $625(49.96 \%)$ & \multirow{2}{*}{$<0.001$} \\
\hline No & $700(60.14 \%)$ & $626(50.04 \%)$ & \\
\hline \multicolumn{4}{|c|}{ Instruction how to perform CPR given by an EMS dispatcher: } \\
\hline Yes & $202(17.35 \%)$ & $287(22.94 \%)$ & \multirow{2}{*}{$<0.001$} \\
\hline No & $962(82.65 \%)$ & $964(77.96 \%)$ & \\
\hline \multicolumn{4}{|l|}{ Return of spontaneous circulation: } \\
\hline Yes & $374(32.13 \%)$ & $362(28.94 \%)$ & \multirow{2}{*}{0.08} \\
\hline No & $790(67.87 \%)$ & 889 (71.06\%) & \\
\hline
\end{tabular}

CPR — cardiopulmonary resuscitation; EMS — emergency medical services

Table 2. Causes of out-of-hospital cardiac arrest (OHCA) and the initial cardiac rhythm recorded by the emergency medical services

\begin{tabular}{|lccc|}
\hline & Urban areas & Rural areas & P \\
\hline Cause of OHCA: & & & \\
Cardiac & $838(71.9 \%)$ & $861(68.8 \%)$ & 0.08 \\
Trauma & $87(7.5 \%)$ & $121(9.8 \%)$ & 0.054 \\
Malignancy & $30(2.6 \%)$ & $22(1.7 \%)$ & 0.16 \\
Respiratory & $153(13.1 \%)$ & $185(14.8 \%)$ & 0.24 \\
No data & $56(4.9 \%)$ & $62(4.9 \%)$ & 0.20 \\
Initial recorded cardiac rhythm: & & \\
Shockable & $227(19.5 \%)$ & $226(18.7 \%)$ & 0.36 \\
Non-shockable & $937(80.5 \%)$ & $1025(81.93 \%)$ & \\
\hline
\end{tabular}

\section{DISCUSSION}

An important factor for patient survival following OHCA is the time to ambulance arrival to the scene, allowing initiation of advanced life support by the EMS team. This is highlighted by

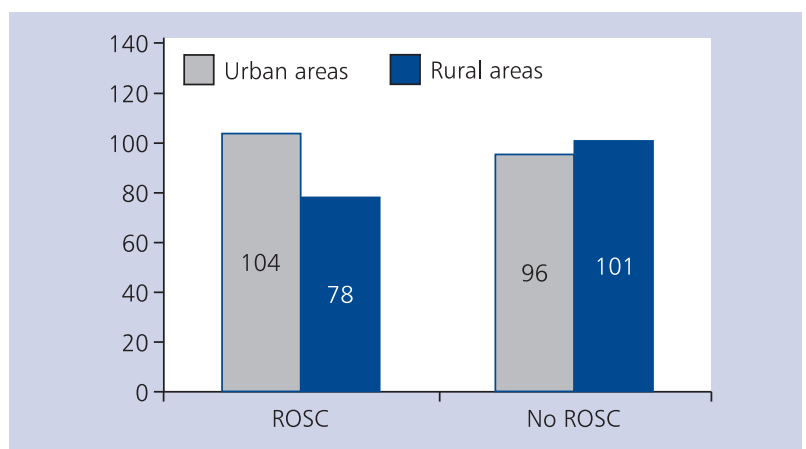

Figure 1. The rates of return of spontaneous circulation (ROSC) in relation to the location of out-of-hospital cardiac arrest in patients with a witnessed event due to cardiac causes and a shockable cardiac rhythm

research studies which resulted in identification of advanced life support as the fourth component of the chain of survival [3]. The time to ambulance arrival to the scene is largely dependent on the distance between the location of OHCA 
and an EMS station. It may be thus hypothesized that in rural areas remote from urban areas where EMS teams are usually stationed, the time from OHCA to initiation of advanced life support including defibrillation will be longer, resulting in a lower rate of ROSC.

A non-shockable rhythm was the first recorded cardiac rhythm in $81 \%$ of all evaluated cases. This proportion is only slightly higher compared to the current data from the United States $(77 \%)$ and confirms a growing trend for OHCA with a non-shockable rhythm that is observed worldwide [2]. This has major importance for patient survival as patients with a shockable rhythm are more likely to survive $[2,12]$. A small number of patients with a shockable rhythm in both studied populations might have affected the observed comparable rates of ROSC in both urban and rural areas.

We found no relation between the location of intervention and the initial recorded ECG. For a comparison, the proportion of shockable rhythms in a similar Australian study was $43.5 \%$ in areas with a low population density and 38.8$-39.8 \%$ in areas with a high population density [9]. Similarly in Stockholm, Sweden, where the population density is high (130 persons $/ \mathrm{km}^{2}$ ) the proportion of shockable rhythms was $21 \%$ compared to $32-33 \%$ in areas with a low population density (2-5 persons $/ \mathrm{km}^{2}$ ) [8].

Cardiac arrest was mostly due to cardiac causes in both urban and rural areas. This observation has been confirmed in Europe and other parts of the world [13, 14]. The reported high rate of OHCA due to cardiac causes my partially result from the way causes of $\mathrm{OHCA}$ are defined of in the Utstein protocol. This category includes not only cases of OHCA due to an evident cardiac cause both also those due to an unclear cause. Our analysis of non-cardiac causes of OHCA revealed that trauma was the second most common cause of OHCA in rural areas. Accidents during farm working are a major problem in Poland. According to the Polish National Institute of Hygiene data, 25,722 such accidents with 81 fatal casualties were reported in 2011 [15]. This may explain the results obtained in our study population. In urban areas, malignancies were the second most common cause for intervention due to OHCA. These differences in regard to the cause of $\mathrm{OHCA}$ in our study were not significant.

In our study, the mean time until ambulance arrival was significantly longer in rural areas. According to data collected in 2013, the mean time until ambulance arrival in selected European countries ranged from 8-19 $\mathrm{min}$ in the United Kingdom to 15-30 min in Lithuania [16].

The mean time until ambulance arrival in fatal cases was nearly $11 \mathrm{~min}$, compared to just over $9 \mathrm{~min}$ in those patients who survived. Similar results indicating a relation between the time to EMS team arrival and the likelihood of ROSC were obtained in Amsterdam [13]. However, the latter study did not evaluate the rate of ROSC in relation to the location of OHCA.

Overall, 85\% cases of OHCA were witnessed. In another Polish study conducted in Katowice, this proportion was
71\% [17]. Unwitnessed OHCA correlates strongly with low survival [2].

Resuscitation efforts were significantly more frequently initiated by the event witnesses in rural areas. Other studies reported varying rates of CPR initiation by the event witnesses, ranging from several to more than $70 \%[8,13,17]$. A difference in the rate of CPR initiation between areas with high and low population density similar to our study was reported in Sweden [8]. The highest rate of CPR initiation was observed in rural areas (77-79\%), while this rate was $61 \%$ in Stockholm. Also in Australia, the rate of CPR initiation by the event witnesses increased from $45 \%$ to $59 \%$ with decreasing population density [9].

In our study, EMS dispatchers significantly more frequently gave instructions for CPR over the phone is OHCA occurred in a rural area. This factor probably affected more frequent initiation of CPR by the event witnesses in this location, with a subsequent effect on the rate of ROSC. Published studies indicate a higher rate of both ROSC and survival until discharge if event witnesses are instructed by an EMS dispatcher how to perform CPR [18].

In our study material, we did not identify any cases of use of an automated external defibrillator by the event witnesses, and thus the time to evaluation of the mechanism of OHCA and any defibrillation attempts was strictly related to the time of ambulance arrival to the scene [19].

Studies indicate that many barriers to effective implementation of all components of the chain of survival still exist. In rural areas, symptoms preceding OHCA were reported less frequently, which might have a negative effect on the first component of the chain of survival. In urban areas, fewer events were witnessed, the event witnesses were less likely to initiate CPR, and EMS dispatchers were less likely to instruct the witnesses how to perform CPR. These factors might have negatively affected the second component of the chain of survival in urban areas. The third and fourth components of the chain of survival in rural areas are limited by the time of EMS team arrival to the scene, resulting from the lack of early defibrillation programs. As a result, the time to defibrillation and initiation of advanced life support correlates closely with the time of ambulance arrival to the scene which is significantly longer in rural areas.

Despite these differences in the characteristics and course of OHCA in rural and urban areas, the observed difference in the rate of ROSC following CPR was not significant. This result is at variance with the results of Australian studies where the rate of ROSC was closely related to the local population density (the lower population density, the higher was the likelihood of ROSC) [9]. Similar rates of ROSC in the two study groups, despite a longer time to the ambulance arrival to the scene in rural areas, are probably related to more frequent initiation of CPR by the event witnesses in rural areas, either independently or with a support from the EMS dispatcher. 
These data confirm that the success of CPR depends mostly on the initiation of CPR by the event witnesses.

\section{Limitations of the study}

In our study, no information was available regarding patient survival until hospital discharge, long-term survival, and post-resuscitation hospital management. The Polish Cardiac Arrest Registry run by the Polish Resuscitation Council is a part of the European Registry of Cardiac Arrest (EuReCa) by the European Resuscitation Council [20, 21]. This registry covers only about $7.6 \%$ of the area of Poland and does not collect data from large cities which limits the ability of extrapolating its results to the whole national population.

Equipment and management standards regarding CPR by EMS are uniform at the national level and thus data collection within a single company should have no significant effect on the study results. Data were collected in various parts of the country and should be representative for the Polish population except for large cities.

\section{CONCLUSIONS}

No significant difference in the rate of ROSC between rural (29\%) and urban (32\%) areas was shown in the study population.

In rural areas, CPR was more frequently initiated by the event witnesses, and EMS dispatchers were more likely to instruct the witnesses over the phone how to perform CPR.

The time of ambulance arrival to the scene was significantly shorter in urban areas (median time 6 min in urban areas compared to $12 \mathrm{~min}$ in rural areas).

Both in urban and rural areas, OHCA was most commonly due to cardiac causes, and the initial recorded cardiac rhythm was a non-shockable one.

\section{Conflict of interest: none declared}

\section{References}

1. Monsieurs KG, Nolan JP, Bossaert LL et al. European Resuscitation Council Guidelines for Resuscitation 2015: Section 1. Executive summary. Resuscitation, 2015; 95: 1-80. doi: 10.1016/j.resuscitation.2015.07.038.

2. Chan PS, McNally B, Tang F, Kellermann A. CARES Surveillance Group. Recent trends in survival from out of hospital cardiac arrest in the United States. Circulation, 2014; 130: 1876-1882. doi: 10.1161/CIRCULATIONAHA.114.009711.

3. Cummins RO, Ornato JP, Thies WH, Pepe PE. Improving survival from sudden cardiac arrest: the "chain of survival" concept. A statement for health professionals from the Advanced Cardiac Life Support Subcommittee and the Emergency Cardiac Care Committee, American Heart Association. Circulation, 1991; 83: 1832-1847. doi: 10.1161/01.CIR.83.5.1832

4. Nichol G, Thomas E, Callaway CW et al. Regional variation in out-of-hospital cardiac arrest incidence and outcome. JAMA, 2008; 300: 1423-1431. doi: 10.1001/jama.300.12.1423.

5. Atwood C, Eisenberg MS, Herlitz J, Rea TD. Incidence of EMS-treated out-of-hospital cardiac arrest in Europe. Resuscitation, 2005; 67: 75-80.
6. Weisfeldt ML, Sitlani CM, Ornato JP et al. Survival after application of automatic external defibrillators before arrival of the emergency medical system: evaluation in the resuscitation outcomes consortium population of 21 million. J Am Coll Cardiol, 2010; 55: 1713-1720. doi: 10.1016/j.jacc.2009.11.077.

7. van Alem AP, Vrenken RH, de Vos R et al. Use of automated external defibrillator by first responders in out of hospital cardiac arrest: prospective controlled trial. BMJ, 2003; 327: 1312.

8. Strömsöe A, Svensson L, Claesson A et al. Association between population density and reported incidence, characteristics and outcome after out-of-hospital cardiac arrest in Sweden. Resuscitation, 2011; 82: 1307-1313. doi: 10.1016/j.resuscitation.2011.04.025.

9. Nehme Z, Andrew E, Cameron PA et al. Population density predicts outcome from out-of-hospital cardiac arrest in Victoria, Australia. Med J Australia, 2014; 200: 471-475.

10. Dmochowska H ed. Mały rocznik statystyczny 2014. Zakład Wydawnictw Statystycznych, 2014, Warszawa.

11. Jacobs I, Nadkarni V, Bahr J et al. International Liaison Committee on Resuscitation. Cardiac arrest and cardiopulmonary resuscitation outcome reports: update and simplification of the Utstein templates for resuscitation registries: a statement for healthcare professionals from a task force of the International Liaison Committee on Resuscitation (American Heart Association, European Resuscitation Council, Australian Resuscitation Council, New Zealand Resuscitation Council, Heart and Stroke Foundation of Canada, InterAmerican Heart Foundation, Resuscitation Council of Southern Africa). Resuscitation, 2004; 63: 233-249. doi: 10.1016/j.resuscitation.2004.09.008.

12. Rudner R, Jałowiecki P, Wartak M et al. Ocena wybranych czynników wpływających na wyniki postępowania resuscytacyjnego w pozaszpitalnych zatrzymaniach krążenia. Anestezjol Intens Ter, 2005; 3: 174-180.

13. Waalewijn RA, de Vos R, Koster RW. Out-of-hospital cardiac arrests in Amsterdam and its surrounding areas: results from the Amsterdam resuscitation study (ARREST) in 'Utstein' style. Resuscitation, 1998; 38: 157-167.

14. Zeliaś A, Stępińska J, Andres J et al. Ten-year experience of an invasive cardiology centre with out-of-hospital cardiac arrest patients admitted for urgent coronary angiography. Kardiol Pol, 2014; 72: 687-699. doi: 10.5603/KP.a2014.0088.

15. Halik R. Wypadki i wypadkowe zatrucia jako zagrożenie zdrowia mieszkańców Polski. Sytuacja zdrowotna ludności Polski i jej uwarunkowania, Warszawa 2012: 239-239.

16. Page Ch, Sbat M, Vazquez K, Yalcin ZD. Analysis of Emergency Medical Systems Across the World, 88, https://www.wpi. edu/Pubs/E-project/Available/E-project-042413-092332/unrestricted/MQFIQP2809.pdf.

17. Rudner R, Jałowiecki P, Karpel E et al. Survival after out-of-hospital cardiac arrests in Katowice (Poland): outcome report according to the "Utstein style". Resuscitation, 2004; 61: 315-325. doi: 10.1016/j. resuscitation.2004.01.020.

18. Rea TD, Eisenberg MS, Culley LL, Becker L. Dispatcher-assisted cardiopulmonary resuscitation and survival in cardiac arrest. Circulation, 2001; 104: 2513-2516.

19. Kuisma M, Määttä T. Out-of-hospital cardiac arrests in Helinsnki — Utstein style reporting. Heart, 1996; 76: 18-23.

20. Gräsner JT, Herlitz J, Koster RW et al. Quality management in resuscitation-towards a European cardiac arrest registry (EuReCa). Resuscitation, 2011; 82: 989-994. doi: 10.1016/j.resuscitation.2011.02.047.

21. Wnent J, Masterson S, Gräsner JT. EuReCa ONE — 27 Nations, ONE Europe, ONE Registry: a prospective observational analysis over one month in 27 resuscitation registries in Europe - the EuReCa ONE study protocol. Scand J Trauma Resusc Emerg Med, 2015; 23: 7. doi: 10.1186/s13049-015-0093-3.

Cite this article as: Cebula GM, Osadnik S, Wysocki M et al. Comparison of the early effects of out-of-hospital resuscitation in selected urban and rural areas in Poland. A preliminary report from the Polish Cardiac Arrest Registry by the Polish Resuscitation Council. Kardiol Pol, 2016; 74: 356-361. doi: 10.5603/KP.a2016.0001. 


\title{
Porównanie wczesnych efektów resuscytacji w pozaszpitalnym nagłym zatrzymaniu krążenia w wybranych obszarach miejskich i wiejskich w Polsce. Wstępny raport Polskiego Rejestru Pozaszpitalnych Zatrzymań Krążenia Polskiej Rady Resuscytacji
}

\author{
Grzegorz M. Cebula ${ }^{1}$, Sonia Osadnik ${ }^{1}$, Michał Wysocki ${ }^{1}$, Marta Dyrda ${ }^{1}, K^{2}$ ja Chmura ${ }^{2}$, \\ Michał Nowakowski², Janusz Andres ${ }^{1}$ \\ 'Wydział Lekarski, Katedra Anestezjologii i Intensywnej Terapii, Uniwersytet Jagielloński Collegium Medicum, Kraków \\ ²Wydział Lekarski, Zakład Dydaktyki Medycznej, Uniwersytet Jagielloński Collegium Medicum, Kraków
}

\section{Streszczenie}

Wstęp: Łańcuch przeżycia jest zespołem najistotniejszych czynników, które wpływają na przeżywalność pacjentów, u których doszło do pozaszpitalnego zatrzymania krążenia. Kluczowe dla poprawy przeżywalności pacjentów są identyfikacja i poprawa najsłabszych elementów tego łańcucha. Jak najszybszy powrót spontanicznego krążenia w wyniku resuscytacji krążeniowo-oddechowej jest warunkiem poprawy przeżywalności po pozaszpitalnym zatrzymaniu krążenia.

Cel: Celem niniejszej pracy była ocena, w jakim stopniu lokalizacja, w której nastąpi zatrzymanie krążenia, wpływa na uzyskanie powrotu spontanicznego krążenia w wyniku podjętej resuscytacji krążeniowo-oddechowej.

Metody: Formularze badania oparte na standardowych wytycznych (Utstein) były wypełnianie przez zespoły ratownictwa medycznego. Rejestr obejmował dane od stycznia 2013 do maja 2014 r. Badaniem objęto obszar o powierzchni 23706 km², w różnych częściach kraju, przy średniej gęstości zaludnienia 90 osób/km². Stanowi to 7,6\% powierzchni Polski, średnia gęstość zaludnienia dla całego kraju wynosi 123 osoby $/ \mathrm{km}^{2}$.

Wyniki: W badanym okresie odnotowano 5185 przypadków zatrzymania krążenia, resuscytację podjęto w 2415 (46,6\%) przypadkach. W 736 (30,48\%) przypadkach uzyskano powrót spontanicznego krążenia, w tym 374 (32,13\%) przypadków na terenach miejskich i 362 (28,94\%) przypadków na terenach wiejskich. Różnica dotycząca częstości powrotu spontanicznego krążenia w badanych grupach nie była istotna statystycznie $(p=0,088)$. W porównaniu z obszarami miejskimi, na terenach wiejskich istotnie częściej świadkowie zdarzenia podejmowali resuscytację oraz otrzymywali instrukcje od dyspozytorów medycznych. W całej badanej grupie najczęstszą przyczyną zatrzymania krążenia były problemy kardiologiczne (70,35\%). Czas przybycia karetki pogotowia na miejsce zdarzenia był istotnie krótszy na terenie miast niż wsi (mediana, odpowiednio, $6 \mathrm{~min}$ i $12 \mathrm{~min}$ ).

Wnioski: Nie wykazano zależności między miejscem zatrzymania krążenia a powrotem spontanicznego krążenia, mimo że czas dojazdu karetki był istotnie krótszy na terenie miast. Na obszarach wiejskich zaobserwowano częstsze podejmowanie resuscytacji przez świadków zdarzenia. Zarówno w mieście, jak i na wsi do zatrzymania krążenia dochodziło najczęściej z przyczyn kardiologicznych, a pierwszy zarejestrowany rytm był rytmem nie do defibrylacji.

Słowa kluczowe: resuscytacja krążeniowo-oddechowa, pozaszpitalne zatrzymanie krążenia, wieś, miasto, łańcuch przeżycia, powrót spontanicznego krążenia

Kardiol Pol 2016; 74, 4: 356-361

\section{Adres do korespondencji:}

dr n. med. Grzegorz M. Cebula, Wydział Lekarski, Katedra Anestezjologii i Intensywnej Terapii, Uniwersytet Jagielloński Collegium Medicum, ul. M. Kopernika 17, 31-501 Kraków, e-mail: grzegorz.cebula@uj.edu.pl

Praca wpłynęła: 02.11.2015 r. Zaakceptowana do druku: 21.12.2015 r.

Data publikacji AoP: 07.01.2015 r 